\title{
A STUDY ON THE IMMUNOMODULATING EFFECT OF GENTAMICIN ON BROILERS VACCINATED WITH NEWCASTLE DISEASE VIRUS
}

\author{
M.F. El Dakroury ${ }^{1}$ and M.M. Elseify ${ }^{2}$ \\ Department of Pharmacology ${ }^{1} \&$ Microology $^{2}$. \\ Animal Health Research Institute, provisional lab Kafer El-Sheikh
}

\begin{abstract}
The aim of the present work is to study immunomodulating effect of gentamicin on broiler chickens vaccinated against Newcastle virus at 18 days and challenged with a virulent strain of ND at the $30^{\text {th }}$ day of age. Three groups of one day old Hubbard chicks each of 30 birds were used in this study. Chicks of the $1^{\text {st }}$ group received $10 \mathrm{mg}$ gentamicin $/ \mathrm{kg} \mathrm{b}$. wt and those of the $2^{\text {nd }}$ group were given $20 \mathrm{mg}$ gentamicin $/ \mathrm{kg} \mathrm{b}$. wt. All the birds of the two groups were injected $S / C$ at $14^{\text {th }}, 15^{\text {th }}$ and $16^{\text {th }}$ days of age . Birds of the $3^{\text {rd }}$ group were used as control non treated group. Blood samples were collected from ten birds of each group at 25 and 35 days of the experiment. Number of dead birds were recorded daily, body weight and feed conversion were estimated weekly till the end of the experiment (at 45 day). Also, the lymphoid organs (thymus, bursa and spleen) were carefully separated \& weighed and each organ relative weight was determined. It was observed that administration of gentamicin $(10 \mathrm{mg} / \mathrm{kg})$ did not induce any significant changes of blood cell count and relative weights of the lymphoid organs. Additionally, it decreased the phagocytic activity, serum total protein and albumin upto 1 week post vaccination. On the other hand, administration of gentamicin $(20 \mathrm{mg} / \mathrm{kg})$ decrease the blood cell count, phagocytic activity and the relative weights of the bursa. Both doses of gentamicin provoked a significant decrease in serum globulin, HI titer and protection \%.
\end{abstract}




\section{INTRODUCTION}

Vaccination is very important for prevention of many diseases. The failure of vaccination is a real problem and can be affected by several factors as pollution, chemicals, infectious agents, hormones and nutrition . Moreover, chemotherapeutic agents play a critical role in stimulation or suppression of the immune response. Under field condition ,it is unusual to run a commercial poultry cycle without some medication as antibiotics \& anticoccidials .

Aminoglycosides, such as gentamicin, are a class of clinically important antibiotics used extensively in the treatment of bacterial infections, particularly against aerobic Gram negative bacteria (Nagai and Takano 2004). After oral administration, gentamicin is not very effective because it is not absorbed to an appreciable extent from the intestinal tract. The recommended routes of administration of gentamicin are intravenous, intramuscular, subcutaneous ,intraperitoneal or topical. All aminoglycosides can cause varying degrees of ototoxicity ,nephrotoxicity and hepatotoxicity (Ali and Goetz.1997;Islam et al., 2011; Giguère et al., 2013 \& Elyazji and Abdel-Aziz 2013). Injections of gentamicin at a dose of $10 \mathrm{mg} / \mathrm{kg}$ b. wt are safe (Khan et al .,2008).

A large number of antibiotics appear to have immunomodulating effects on the animal (Yourtee and Root,1984). The concept of immunostimulating effect relates to non - specific activation of the immune system implying a non - antigen dependent stimulation of the function and efficiency of macrophages, lymphocytes ...etc. Being non 
specific, it is expected to give protection against different pathogens including viruses, bacteria and fungi and constitutes an alternative or adjunct to conventional chemotherapy.

Some antibiotics have been found to suppressed the immune response particularly ampicilline (Miyata et al., 1998), tylosin (Abdelfattah et al., 2004), tetracycline (Van-Valem et al., 1996), sulphadimidine, (Al-ankari et al., 1996) and chloramphinicol (Rzedzicki et al., 1991). Other antibiotics work to strength the immune response of the animal as enreofloxacin (Abdel-fattah et al., 2004), macrolide (Martin et al., 1980 \&Shryock et al., 1998) and flumequine (Mansurud-Din et al .,2007).

The present work was designed to shed some light on the immunomodulating effects of gentamicin on broilers vaccinated with Newcastle Disease virus.

\section{MATERIALS AND METHODS}

\section{Drug:}

Gentamicin(Ato-Gent)was purchased from Atco -Pharma.

\section{Newcastle Challenge strain:}

A local velogenic viscerotropic strain of New castle Disease Virus(NDV) was obtained from the Veterinary institute for biological products and vaccines (Abbasia,Cairo).

\section{Chickens:}

Ninety, one day old Hubbard chicks were used in the present study. The chicks were floor reared in experimental rooms bedded by chaffed 
wood and provided with clean feeders and drinkers. They were fed a balanced commercial poultry ration. No drugs or vaccines were given to the chickens along the coarse of experiment except those under investigation.

\section{Experimental design:}

The chicks were divided into three equal groups, each of 30 chick. The $1 \mathrm{st}$ group received $10 \mathrm{mg}$ gentamicin $/ \mathrm{kg} \mathrm{b}$. wt S/C at $14 \mathrm{th}, 15$ th and 16 th days of age. The 2 nd group received $20 \mathrm{mg}$ gentamicin $/ \mathrm{kg} \mathrm{b}$. wt $\mathrm{S} / \mathrm{C}$ at the same period. The $3^{\text {rd }}$ group was left as a vaccinated control group without drug treatment. All birds were given Newcastle disease virus vaccine (Lasota) at $18^{\text {th }}$ day of age.

All groups were challenged with a virulent strain of ND at the $e^{30 t h}$ day of age. At 25 and 35 day of the experiment, blood samples were collected from ten birds of each group. The experimental period lasted for 45 days. The live body weight of all birds and the total amount of feed intake were recorded weekly. The final live body weight was obtained and the feed conversion was calculated (feed intake / weight gain). Number of dead birds were also recorded throughout the experiment. Protection \% was recorded for each group (number of survived birds / number of challenged birds). Birds were sacrificed at 45 days then the lymphoid organs (thymus, bursa and spleen) were carefully separated \&weighed and each organ relative weight was determined.

\section{Laboratory examinations:}

Phagocytic activity was estimated according to Barry et al. (1989). Total erythrocytic and leukocytic counts were evaluated according to 
Natt and Herrick, (1952). Blood film was prepared and stained with Giemsa stain for differential leukocytic count according to Schalm et al., (1975).

Determination of serum total protein was performed according to Doumas et. al. (1981). Fractions of serum proteins were detected by using polyacrylamid gel electrophoresis as described by Laemmli(1970). Statistical analysis:

All obtained data were recorded and analyzed statistically by Gomez and Gomez, (1984).

\section{RESULTS}

The obtained data presented in tables from (1) to (6) showed that the administration of gentamicin $(10 \mathrm{mg} / \mathrm{kg})$ did not induce any significant changes of blood cell count and relative weights of the lymphoid organs. Also, it decreased the phagocytic activity, serum total protein and albumin upto 1 week post vaccination. On the other hand, administration of gentamicin $(20 \mathrm{mg} / \mathrm{kg})$ decrease the number of blood cell count, phagocytic activity and the relative weights of the bursa. Additionally, both doses of gentamicin provoked a significant decrease in HI titer and serum gammaglobulin. Moreover, challenge of treated chickens with Newcastle disease virus resulted in $83 \%$ and $70 \%$ protection for recommended and double doses of gentamicin respectively compared with $90 \%$ protection for vaccinated non treated bird . 
Table (1): Effect of gentamicin administration on the total serum protein, albumin and globulin(g/dL).

\begin{tabular}{|c|c|c|c|c|c|c|}
\hline \multirow{2}{*}{ Age } & \multirow{2}{*}{ Treatments } & \multirow{2}{*}{$\begin{array}{c}\text { Total serum } \\
\text { protein }\end{array}$} & \multirow{2}{*}{ Serum albumin } & \multicolumn{3}{|c|}{ Serum globulin } \\
\hline & & & & Alpha globulin & Beta globulin & Gammaglobulin \\
\hline \multirow{3}{*}{25 day } & $\begin{array}{l}\text { Gentamicin } \\
(10 \mathrm{mg} / \mathrm{kg})\end{array}$ & $4.29 \pm 0.26^{\mathrm{b}}$ & $2.23 \pm 0.13^{\mathrm{b}}$ & $0.6 .9 \pm 0.41^{b}$ & $0.87 \pm 0.74^{b}$ & $0.50 \pm 0.22^{\mathrm{b}}$ \\
\hline & $\begin{array}{c}\text { Gentamicin }(20 \\
\mathrm{mg} / \mathrm{kg})\end{array}$ & $3.61 \pm 0.18^{c}$ & $1.89 \pm 0.96^{\mathrm{c}}$ & $0.61 \pm 0.3^{\mathrm{c}}$ & $0.72 \pm 0.31^{\mathrm{c}}$ & $0.39 \pm 0.31^{\mathrm{c}}$ \\
\hline & Control & $4.73 \pm 0.42^{\mathrm{a}}$ & $2.41 \pm 0.24^{\mathrm{a}}$ & $0.77 \pm 0.53^{\mathrm{a}}$ & $0 . .96 \pm 0.81^{\mathrm{a}}$ & $0.58 \pm 0.44^{\mathrm{a}}$ \\
\hline \multirow{3}{*}{35 day } & $\begin{array}{l}\text { Gentamicin } \\
(10 \mathrm{mg} / \mathrm{kg})\end{array}$ & $4.30 \pm 0.65^{\mathrm{a}}$ & $2.36 \pm 0.21^{\mathrm{a}}$ & $0.79 \pm 0.46^{\mathrm{a}}$ & $0.85 \pm 0.86^{\mathrm{b}}$ & $0.30 \pm 0.42^{b}$ \\
\hline & $\begin{array}{c}\text { Gentamicin }(20 \\
\mathrm{mg} / \mathrm{kg})\end{array}$ & $3.41 \pm 0.18^{b}$ & $1.84 \pm 0.91^{\mathrm{b}}$ & $0.65 \pm 0.29^{b}$ & $0.73 \pm 0.61^{\mathrm{c}}$ & $0.19 \pm 0.31^{\mathrm{c}}$ \\
\hline & Control & $4.42 \pm 0.33^{\mathrm{a}}$ & $2.33 \pm 0.16^{\mathrm{a}}$ & $0.75 \pm 0.43^{\mathrm{a}}$ & $0.97 \pm 0.78^{\mathrm{a}}$ & $0.37 \pm 0.23^{\mathrm{a}}$ \\
\hline
\end{tabular}

Means followed by a common letter are not significantly different at 5\% level by DMRT.

Table (2): Effect of gentamicin administration on blood cell count, phagocytic activity and (HI) antibody titer $(\log 2)$.

\begin{tabular}{|c|c|c|c|c|c|}
\hline Age & Treatment & $\begin{array}{l}\text { Total RBcs } \\
\text { count }\left(10^{6} / \mu \mathrm{l}\right)\end{array}$ & $\begin{array}{l}\text { Total leukocytic count } \\
\text { (X } 1000 \text { cells / cmm) }\end{array}$ & $\begin{array}{l}\text { phagocytic } \\
\text { activity }\end{array}$ & HI titer \\
\hline \multirow{3}{*}{25 day } & $\begin{array}{l}\text { Gentamicin } \\
(10 \mathrm{mg} / \mathrm{kg})\end{array}$ & $3.27 \pm 0.01^{\mathrm{a}}$ & $38.3 \pm 3.2^{\mathrm{a}}$ & $22.15+0.64^{b}$ & $5.0 \pm 0.54^{b}$ \\
\hline & $\begin{array}{l}\text { Gentamicin } \\
(20 \mathrm{mg} / \mathrm{kg})\end{array}$ & $2.42 \pm 0.02^{\mathrm{b}}$ & $29.6 \pm 1.8^{\mathrm{b}}$ & $21.24+0.24^{b}$ & $4.3 \pm 0.43^{\mathrm{c}}$ \\
\hline & Control & $3.36 \pm 0.02^{\mathrm{a}}$ & $39.0 \pm 2.6^{\mathrm{a}}$ & $24.38+0.64^{\mathrm{a}}$ & $6.5 \pm 0.58^{\mathrm{a}}$ \\
\hline \multirow{3}{*}{35 day } & $\begin{array}{l}\text { Gentamicin } \\
(10 \mathrm{mg} / \mathrm{kg})\end{array}$ & $3.31 \pm 0.32^{\mathrm{a}}$ & $38.8 \pm 4.1^{\mathrm{a}}$ & $22.74 \pm 0.58^{\mathrm{a}}$ & $5.5 \pm 0.61^{\mathrm{b}}$ \\
\hline & $\begin{array}{l}\text { Gentamicin } \\
(20 \mathrm{mg} / \mathrm{kg})\end{array}$ & $2.56 \pm 0.29^{b}$ & $29.2 \pm 2.4^{\mathrm{b}}$ & $20.67 \pm 0.58^{b}$ & $4.5 \pm 52^{c}$ \\
\hline & Control & $3.54 \pm 0.38^{\mathrm{a}}$ & $39.3 \pm 4.7^{\mathrm{a}}$ & $23.33 \pm 0.58^{\mathrm{a}}$ & $6.8 \pm 0.41^{\mathrm{a}}$ \\
\hline
\end{tabular}

Means followed by a common letter are not significantly different at 5\% level by DMRT.

$\overline{\text { Kafrelsheikh Vet. Med. J. Vol. } 12 \text { No. } 2 \text { (2014) }}$ 
A Study On The Immunomodulating Effect Of ...

Table (3): Effect of gentamicin administration on differential leukocytic count

\begin{tabular}{|c|c|c|c|c|c|c|}
\hline Age & Treatments & $\begin{array}{c}\text { Blood } \\
\text { monocytes }(\%)\end{array}$ & $\begin{array}{c}\text { Blood } \\
\text { lymphocytes }(\%)\end{array}$ & $\begin{array}{c}\text { Blood } \\
\text { heterophils }(\%)\end{array}$ & $\begin{array}{c}\text { Blood } \\
\text { esinophils }(\%)\end{array}$ & $\begin{array}{c}\text { Blood } \\
\text { basiophils }(\%)\end{array}$ \\
\hline \multirow{3}{*}{25 day } & $\begin{array}{l}\text { Gentamicin } \\
(10 \mathrm{mg} / \mathrm{kg})\end{array}$ & $9.7 \mathrm{~ns} \pm 0.36$ & $63.0 \mathrm{~ns} \pm 1.14$ & $23.6 \mathrm{~ns} \pm 0.56$ & $2.4 \mathrm{~ns} \pm 0.45$ & $1.3 \mathrm{~ns} \pm 0.37$ \\
\hline & $\begin{array}{l}\text { Gentamicin } \\
(20 \mathrm{mg} / \mathrm{kg})\end{array}$ & $10.10 \mathrm{~ns}+0.43$ & $62.6 \mathrm{~ns}+0.82$ & $23.4 \mathrm{~ns}+0.45$ & $2.5 \mathrm{~ns} \pm 0.23$ & $1.4 \mathrm{~ns} \pm 0.48$ \\
\hline & Control & $9.4 \pm 0.25$ & $65.1 \pm 1.32$ & $21.7 \pm 0.83$ & $2.4 \pm 0.43$ & $1.4 \pm 0.37$ \\
\hline \multirow{3}{*}{35 day } & $\begin{array}{l}\text { Gentamicin } \\
(10 \mathrm{mg} / \mathrm{kg})\end{array}$ & $11.8 \mathrm{~ns}+0.50$ & $60.6 \mathrm{~ns}+1.03$ & $24.5 \mathrm{~ns}+5.97$ & $1.3 \mathrm{~ns}+0 . .32$ & $1.8 \mathrm{~ns}+0.53$ \\
\hline & $\begin{array}{l}\text { Gentamicin } \\
(20 \mathrm{mg} / \mathrm{kg})\end{array}$ & $11.7 \mathrm{~ns}+0.48$ & $59.5 \mathrm{~ns}+0.92$ & $26.2 \mathrm{~ns}+3.81$ & $1.3 \mathrm{~ns}+0.31$ & $1.3 \mathrm{~ns}+0.24$ \\
\hline & Control & $11.4 \pm 0.42$ & $61.7 \pm 1.10$ & $23.7 \pm 9.03$ & $1.5 \pm 0.41$ & $1.7 \pm 0.5$ \\
\hline
\end{tabular}

$\mathrm{Ns}=$ non significant

Table (4): Live body weight in grams in chickens throughout the experimental period.

\begin{tabular}{|c|c|c|c|c|c|c|c|c|}
\hline Treatment & O day & Ist week & $2^{\text {nd }}$ week & 3rd week & $4^{\text {th }}$ week & $5^{\text {th }}$ week & $6^{\text {th }}$ week & $\begin{array}{c}\text { Final body } \\
\text { weight }\end{array}$ \\
\hline $\begin{array}{c}\text { Gentamicin } \\
(10 \mathrm{mg} / \mathrm{kg}) \text { at } \\
14^{\text {th }}, 15^{\text {th }} \text { and } \\
16^{\text {th }} \text { day }\end{array}$ & $40.9 \pm 1.1$ & $138 \pm 7.2$ & $347 \pm 32.4$ & $542 \pm 18.7$ & $997 \pm 19.2^{\mathrm{b}}$ & $1412 \pm 31.8^{b}$ & $1808 \pm 25.6^{b}$ & $1935 \pm 37.8^{b}$ \\
\hline $\begin{array}{c}\text { Gentamicin } \\
(20 \mathrm{mg} / \mathrm{kg}) \text { at } \\
14^{\text {th }}, 15^{\text {th }} \text { and } \\
16^{\text {th }} \text { day }\end{array}$ & $42.1 \pm 1.2$ & $140 \pm 9.5$ & $365 \pm 25.7$ & $564 \pm 23.4$ & $962 \pm 21.4^{\mathrm{b}}$ & $1388 \pm 23.4^{b}$ & $1663 \pm 24.3^{\mathrm{c}}$ & $1818 \pm 41.1^{\mathrm{c}}$ \\
\hline Control & $39.8 \pm 1.4$ & $132 \pm 6.6$ & $355 \pm 24.5$ & $587 \pm 19.7$ & $1123 \pm 29.8^{\mathrm{a}}$ & $1568 \pm 39 . .5^{\mathrm{a}}$ & $1963 \pm 21.5^{\mathrm{a}}$ & $2148 \pm 32.1^{a}$ \\
\hline
\end{tabular}

Means followed by a common letter are not significantly different at $5 \%$ level by DMRT.

Kafrelsheikh Vet. Med. J. Vol. 12 No. 2 (2014) 
Table (5): Effect of gentamicin administration on feed conversion and protection percentage against challenge with a virulent Newcastle disease virus in broiler chickens vaccinated with NDV.

\begin{tabular}{|c||c||c|}
\hline Treatment & Feed conversion & protection percentage \\
\hline \hline Gentamicin $(10 \mathrm{mg} / \mathrm{kg})$ & $2.05 \pm 0.024^{\mathrm{c}}$ & $\% 83$ \\
\hline Gentamicin $(20 \mathrm{mg} / \mathrm{kg})$ & $2.19 \pm 0.048^{\mathrm{b}}$ & $\% 70$ \\
\hline \hline Control & $\mathbf{1 . 8 3} \pm \mathbf{0 . 0 8 9}$ & $\% \mathbf{9 0}$ \\
\hline
\end{tabular}

Means followed by a common letter are not significantly different at $5 \%$ level by DMRT.

Table (6): Effect of gentamicin administration on the relative weight of bursa, spleen and thymus.

\begin{tabular}{|c|c|c|c|}
\hline Preatments & Bursa relative weight & Spleen relative weight & Thymus relative weight \\
\hline Gentamicin $(10 \mathrm{mg} / \mathrm{kg})$ & $2.125 \pm 0.165^{\mathrm{a}}$ & $1.782 \pm 0.136$ & $2.211 \pm 0.183$ \\
\hline Gentamicin $(20 \mathrm{mg} / \mathrm{kg})$ & $1.525 \pm .231^{\mathrm{b}}$ & $1.768 \pm 0.126$ & $2.136 \pm 0.237$ \\
\hline Control & $2.342 \pm 0.152^{\mathrm{a}}$ & $1.811 \pm 0.142$ & $2.245 \pm 0.190$ \\
\hline
\end{tabular}

Means followed by a common letter are not significantly different at $5 \%$ level by DMRT.

\section{DISCUSSION}

The obtained data revealed that gentamicin mainly at a dose of 20 $\mathrm{mg} / \mathrm{kg}$ significantly suppressed the immune response of birds where it decreased serum total proteins, relative weight of bursa, phagocytic activity, $\mathrm{HI}$ titer and protection percentage. The fore mentioned finding fits neatly with those narrated by Arivuchelvan et al., (2012). The authors reported that gentamicin produced significant reduction in serum total protein, albumin and globulin beside numerical decrease in HI titer against Newcastle vaccine. Also, Saleemi et al., (2009) reported that

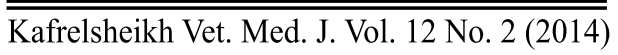


serum total proteins, albumin and weight gain decreased while creatinine and ALT increased in chicks given $20 \mathrm{mg} / \mathrm{kg}$ and higher doses of gentamicin. The no observable effect level (NOEL) of a single intramuscular administration of gentamicin in day-old broiler chicks was $10 \mathrm{mg} / \mathrm{kg}$ body weight. The reduction in serum total protein might be due to inhibition of protein synthesis by gentamicin (Buss et al.,1985).

On the other hand, Asha et al. (1999) mentioned that gentamicin at levels of $4 \mathrm{mg} / \mathrm{kg}$ and $8 \mathrm{mg} / \mathrm{kg}$ b. wt doses in rabbits had no significant effect on the immune response and this may be due to species variation beside using low doses of gentamicin.

The data in table (1) \& (2) cleared that both doses of gentamicin elicited a significant decreases in $\mathrm{HI}$ antibody titer and serum gammaglobulin. These results are in accordance with Naqi et al., (1984) who mentioned that gentamicin decreases all serum immunoglobulins fractions in chickens. On similar grounds, Sakaeva and Lazareva (1998) found out that administration of gentamicin deepens the severe suppression of antibody genesis against the background of cyclophosphan in mice.

The decreased antibody titer in chicks given gentamicin may be due to the decreased number of leukocytes especially lymphocytes. The decreased gamma globulin level, which is the main source of antibodies synthesis could be another explanation (Coles, 1986). It is well known that B.lymphocytes developed in the bursa of Fabricius .It play an important role in antibody production (Tizard, 2000) so ability of gentamicin $(20 \mathrm{mg} / \mathrm{kg})$ to induce a significant decrease in bursa / body weight ratio may be responsible for the decreases of antibody titer

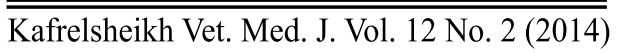


recorded in this study. The low number of blood cell in gentamicin $(20 \mathrm{mg} / \mathrm{kg}$ ) treated group (table 2) may be due to inhibition of protein synthesis which is important for cell mitosis (Laurence and Bennet, 1985).

The present results demonstrated that gentamicin $(20 \mathrm{mg} / \mathrm{kg})$ significantly decreased the phagocytic activity (table2). The findings reported by Ziv, et al., (1983) are in agreement with the present result. The authors recorded that gentamicin had adverse effects on phagocytic capability of cattle phagocytes. The ability of gentamicin to decrease phagocytic capacity may be through alteration of phagocytic cell surface. This explanation was confirmed by Paape et al., (1990) who observed that gentamicin decreased the phagocytosis through alteration of polymorphnuclear leukocytes morphology.

In conclusion, the present study showed that gentamicin had a dose dependant immunosuppressive effect on broilers. In accordance and to have efficient vaccination, higher doses of gentamicin should be avoided.

\section{REFERENCES}

- Abdel-fattah, M.A.F;Khhalil,W.F. and Fayez, M.M.(2004): Effect of tylosin and enrofloxacin on the immune response of broiler chickens vaccinated with Newcastle disease vaccine .J. Egypt. Soc. Pharmacol. Exp. Ther., vol 24 no.1 jan 2004.

- Al-Ankari, A.S and Homeida, A.M (1996): Effect of antibacterial growth promoters on the immune system of broiler chicks. VetImmunol-Immunopathol. 1996 Oct; 53(3-4): 277-283. 
- Ali MZ and Goetz MB(1997): A meta-analysis of the relative efficacy and toxicity of single daily dosing versus multiple daily dosing of aminoglycosides. Clin Infect Dis 1997;24:796-809.

- Arivuchelvan,A;: Murugesan, S; Mekala, P. and Yogeswari, R. (2012): Immunomodulatory effect of Ocimum sanctum in broilers treated with high doses of gentamicin . Indian Journal of Drugs and Diseases. Vol.1 No.5 (Aug. 2012).pp109-112

- Artsimovich, N. ; Nastoiashchaia N.; Mul'tanovskaia V.; Matvienko M. and Navashin, P.( 1991): Study of the immunotropic activity of aminoglycoside antibiotics. Antibiot Khimioter. 1991 Feb;36(2):27-9.

- Asha, H; Honne, G,; Narayana, K.; Krishnappa, G. and Jayakumar, K. (1999): Effect of gentamicin on specific immune response in rabbits. Indian J. pharmacology .1999 31 (3) : 229-231

- Barry L., Ghamon, U., John R., and Glisson A. (1989): In vitro microbial activity of avian pertoneal macrophages. Avian diseases. 23 (1):177-181

- Buss WC,Robert Kauten and Keith Piatt M (1985): Inhibitory effects of gentamicin and ethacrynic acid on mammalian microsomal protein synthesis. J.Antimicrob. Chemother.15, 105-113.

- Coles, D, V, M. (1986): Veterinary clinical pathology. Fourth edition. W.B.Saunders Company Philadelphia- London-toranto .pp279-290.

- Doumas, B.T.; Bayso, D.D.; Carter, R.J.; Peters, T. and Schaffer, R. (1981): Determination of total serum protien. Clin. Chem., 27:16421643. 
- Elyazji ,N, R. and, Abdel-Aziz,I (2013): Some hematological and physiological changes associated with gentamicin and/or novalgen injection $\mathrm{n}$ rabbits. International journal of pharmaceutical, chemical and biological sciences 2013, 3(1), 172-181.

- Giguère, S.; Prescott, J. and Dowling, P. (2013): Antimicrobial Therapy in Veterinary Medicine. Fifth Edition.

- Gomez, K. A. and Gomez, A. A. (1984): Statistical procedures for Agriculture Reseach. John Willey and Sons. New York .USA pp 680.

- Islam, N.U.; Khan M.Z. ;Saleemi, M.K. ;Khan, A..; Bhatti, S.A; Yousaf, M.and Hassan, Z.U (2011). Clinicopathological studies on gentamicin toxicity in White Leghorn commercial layers. Pak. Vet. J., 31: $305-308$.

- Khan, I.; Khan, M.Z.; Saleemi, M.K.; Javed, I. and Khan, A.( 2008): Pathological and biochemical effects of intramuscular gentamicin administration in chicken. Turkish. Journal of Veterinary and Animal Sciences, 32: 345-351.

- Laemmli, U. K. (1970): Structural proteins during the assembly of head of bacteriophage T4 .Natue ,227(15):680.

- Laurence, D. R. and Bennet, P. N. (1985): Clinical pharmacology 5th edition. Churchill Livingstone, pp.191-234.

- Mansur-ud-Din A.;Abbas W.;Muneer,M.A.;Hussain I.and Hanif A. (2007): Immunomodulatory Effects of Flumequine and Enrofloxacin on Newcastle Disease Virus Vaccinated Broiler Chicks. Pak. j. life soc. sci. (2007), 5(1-2): 24-29. 
- Martin RR; Putname, M., Greenberg, S. B.; Wallace, R. J. and Wilson,S. Z.(1980): Serial studieds of leucocyte chemiluminescence: lack of effect of macrolide antibiotic therapy. J. Medicine. 11:39-48.

- Myata, T. and Shinohara, M. (1985): effect of antibiotics on rat leukocyte function.j. Osaka .Dent. Univ .1998 Apr ,32(1): 9-15.

- Natt, M.P and Herrick, C.A. (1952): A new blood diluent for counting the red and white blood cells of the chicken. Poultry Science., 31:335.

- Nagai J, Takano M., (2004): Molecular aspects of renal handling of aminoglycosides and strategies for preventing the nephrotoxicity. Drug Metab Pharmacokinet 19, 159-70.

- Naqi, S.A., Sahin, N., Wagner, G. and Williams, 3. (1984). Adverse effects of antibiotics on the development of gut-associated lymphoid tissues and serum immunoglobulins in chickens. Am. j. Vet. Res. 45: 1425-1429.

- Paape, M. J; Nickerson, S. C; and ziv, G. (1990): in vivo effects of chloramphenicol ,tetracycline, and gentamicin on bovine neutrophil function and morphologic features. Am. J. Vet Res, vol 51, No.7, july 1990.

- Rzedzicki, J., Cybulska, R.,; Traminska, B. and Jaworska-Adamu. J. (1991). Effect of some antibacterial agents on the immune response and intestinal mucosa of chickens Vetrynaria . 49:179-189.

- Sakaeva D.D. and Lazareva D.N. (1998): The effect of gentamycin on immunity in immunodeficiency and the action of immunomodulators. Eksp Klin Farmakol. 1998 May-Jun;61(3):50-3. 
- Saleemi, K. M.; Khan, Z. M.; Javed, I.and Khan, A. (2009): Pathological effects of gentamicin administered intramuscularly to day-old broiler chicks. Experimental and Toxicologic Pathology Volume 61, Issue 5, September 2009, Pages 425-434.

- Schalm, O. W.; Jain, N. C. and Carroll, E. J. (1975): Veterinary Haematology, $3^{\text {rd }}$ ED. Lea and Febiger , Philadelphia

- Shryock, T.R.; Mortensen, J.E.; Baumholtz, M. (1998). The effects of macrolides on the expression of bacterial virulence mechanisms. J.Antimicrobial Chemotherapy, 41+505-512.

- Tizard I. R. (2000): Veterinary immunology an introduction .Sixth edition 2000. W.B.Saunders Company. A Har Court Health Sciences Company Philadelphia- London -toronta - montereal

- Van-Vlem, B; Vanh older, R; De-Paepe,P; Vogelaers, D and Ringoir, S. (1996): Immunomodulating effects of antibiotics: literature review .Infection 1996 Jul-Aug; 24(4): 275-91Vet-ImmunolImmunopathol.1996 Oct; 53(3-4): 277-83.

- Yourtee, E. L. and Root, R. K. (1984). Effect of antibiotics on phagocyte microbe interactions. InNew Dimentions In Antimicrobial therapy (Root, R.K. and Sande, M.,Eds),pp243-275. Churchill, Livingstone, New York.

- Ziv, G.; Paape, M.3. and Dulin, A.M. (1983). Influence of antibiotics and intramammary products on phagocytosis of Staphylococcus cureus by bovine leukocytes.Am. 3. Vet. Res. 44: 385-388. 
دراسة علي التأثير المناعي للجنتامايسين على الاجاج المحصن بلقاح نيوكاسل

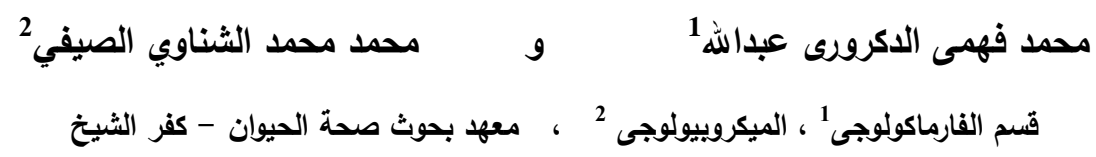

استهدف هذا البحث دراسة تأثثرات استخدام الجنتامايسين على الاستجابة المناعية لدجاج النسمين المحصن بلقاح النيوكاسل ق قسمت الكتاكيث إلى ثلاث مجموعات منساوية كل منها تحتوى على 30 كتكوت المجموعة الأولى تم حقنها بالجنتامايسين (10 mg/kg). في اليوم 14و15و16 بينما المجموعة الثانية فقد حقنها بالجنتامايسين (20mg/kg) فى نفس المدة أما المجموعة الأخيرة فكانت مجموعه ضابطه،تم تحصين جميع الطيور بلقاح لاسوتا في اليوم 18 وعند اليوم 30 تم العدوى بفيروس النيوكاسل.عند يوم 25 و 35 من بداية التجربة تم اخذ عينات الدم من الطيور في كل المجموعات لإجراء عدد من الفحوص المختلفة: معدل التحويل الغذائي ونسبه النفوق تم تسجيلهم بنهاية التجربة عند عمر 45 يوم وكذلك تم حساب الوزن النسبي للغدة الزعنريه وغدة البرسافابريش والطحال

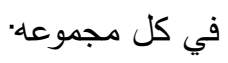

وقد اتضح من هذه الدراسة أن استخدام العقار بكلى الجرعتنن السابقتين أدى إلى نقص ملموس في مستوى الجلوبيولين والأجسام المناعية لمنع التلازن الدموي ضد فيروس النيوكاسل. لم بحدث أي تأثثر ملموس على العدد الكلى لخلايا الدم الحمراء والبيضاء ووزن الأعضاء الليمفاوية عند استخدام الجرعة الأولى من العقار بينما أحدثت الجرعة المضاعفة نقا ملموسا في الوزن النسبي لغدة البرسافابريش والعدد الكلى لخلايا الدم الحمراء والبيضاء والنشاط البلعمي: على الجانب الآخر وصلت نسبه الحماية إلى 83\% في المجموعة الأولى عند العدوى المباشرة بفيروس النيوكاسل وانخفضت إلى 70 في المجموعة الثانية بينما وصلت إلى 90\% في المجموعة الضابطة. 